Политическая культура

и идеология

\title{
С.Б. Маргулис
}

Российская академия народного хозяйства

и государственной службы

при Президенте Российской Федерации,

119571 г. Москва, Российская Федерация

\section{К вопросу о теоретических основах и историческом развитии радикального ислама как политической идеологии}

Целью статьи является краткий анализ теоретических основ радикального исламизма как политической идеологии и рассмотрение основных исторических этапов его формирования на примерах высказываний конкретных религиозно-политических деятелей. В рамках статьи приводятся основные положения теоретиков радикального ислама, на идеологической базе которых действуют современные экстремистские группировки, такие как «Исламское государство», «Аль-Каида», «Хизбут-Тахрир» и многие другие. Автор обращается к Корану и сборнику хадисов «Муснад» Ахмада ибн Ханбаля, а также трудам Ибн Таймии, Ибн Ваххаба, Хасана аль-Банны, Сейида Кутба, Абу-ль-Аля Маудуди и т.д., а также трудам отечественных и зарубежных ученых, занимающихся данной проблематикой. Первая часть статьи посвящена базовым постулатам радикального ислама, вторая сосредоточена на их практическом воплощении в политической практике мусульманских государств. По мнению автора, на протяжении истории исламский радикализм периодически получал существенное распространение как один из ответов мусульманского мира, с одной стороны, 
лОКУС: люди, общество, культуры, смыслы. 2020. Т. 11. № 2

на внешнее давление, а с другой - на процессы, происходящие внутри самого исламского мира, которые определенная группа «ревнителей» трактовала как отступление от истинного смысла данной религии.

Ключевые слова: религия, радикальный ислам, исламизм, мусульмане, исламский фундаментализм, идеология

ССЫЛКА НА СТАТЬЮ: Маргулис С.Б. К вопросу о теоретических основах и историческом развитии радикального ислама как политической идеологии // Локус: люди, общество, культуры, смыслы. 2020. Т. 11. № 2. С. 88-105. DOI: 10.31862/2500-2988-2020-11-2-88-105

DOI: 10.31862/2500-2988-2020-11-2-88-105

\title{
S.B. Margulis
}

\author{
Russian Presidential Academy of National Economy \\ and Public Administration, \\ Moscow, 119571, Russian Federation
}

\section{On the theoretical foundations and historical development of radical Islam as a political ideology}

The purpose of this article is the analysis of the theoretical foundations of radical Islamism as a political ideology and consideration of the main historical stages of its formation, on the examples of specific religious and political figures. The article presents the main principles of the theorists of radical Islam, on the ideological basis of which there are modern extremist groups such as "Islamic State", "Al-Qaeda", "Hizbut-Tahrir" and many others.The author addresses the Koran and the collection of Hadiths "Musnad" by Ahmad ibn Hanbal, as well as the works of Ibn Taymiyyah, Ibn Wahhab, Hassan al-Banna, Seyyid Kutub, Abu al-Al Al-Maududi, etc., as well as the works of local and foreign scholars in this research area. The article is divided into two main parts, the first of which is devoted to the basic postulates of radical Islam, the second is focused on their practical implementation in the political practice of Muslim States. The author came to the conclusion that throughout the history Islamic radicalis periodically received a substantial distribution as one 
of the answers of the Muslim world, on the one hand, to external pressure, and on the other to the processes happening within itself that a certain group of "zealots" interpreted as the deviation from the true meaning of the religion.

Key words: Religion, radical Islam, Islamism, Muslims, Islamic fundamentalism, ideology

CITATION: Margulis S.B. On the theoretical foundations and historical development of radical Islam as a political ideology. Locus: People, Society, Cultures, Meanings. 2020. Vol. 11. No. 2. Pp. 88-105. (In Russ.) DOI: 10.31862/2500-29882020-11-2-88-105

Начиная со второй половины XX в. в мусульманском мире наметились существенные политические и социально-экономические изменения. В современном исламском социуме все больше стал проявляться феномен так называемого исламского радикализма или фундаментализма, причем в глобальном масштабе. На многих территориях компактного проживания мусульман возникло немалое число религиознополитических организаций, группировок и сект, продвигающих идею установления подлинного исламского правления в отдельно взятой стране, регионе или мире в целом путем борьбы с «неверными». Подобные радикальные структуры активно действовали и продолжают действовать в таких регионах, как Ближний Восток, Центральная и ЮгоВосточная Азия, Северный Кавказ и т.д. Многие группировки прибегают к откровенно экстремистским методам противостояния своим идеологическим противникам, обращаясь к так называемому малому или боевому джихаду, и становятся угрозой всему мировому сообществу. Для успешного противостояния мировому исламизму необходимо качественное научное осмысление идеологической базы фундаменталистов.

Целью настоящей работы является краткий анализ теоретических основ радикального исламизма как политической идеологии и рассмотрение основных исторических этапов его формирования, на примерах конкретных религиозно-политических деятелей.

Проблема радикального ислама рассматривалась в работах отечественных ученых: А. Игнатенко, Г. Милославского, И. Добаева, А. Коровикова, а также зарубежных специалистов таких, как Г. Фуллер, Д. Пайпс и др. Исламизм на Ближнем Востоке изучали П. Берген, Л. Райт, С. Демиденко, Г. Мирский. Ситуацию в Центральной Азии рассматривали А. Нанаева, Б.Бабаджанов, М. Олкотт и др. О фундаментализме в Юго-Восточной Азии писали Е. Канаева и Н. Рогожина. При этом, несмотря на достаточно большое количество научных трудов, тема не является достаточно изученной и требует дальнейших исследований. 
лОКУС: люди, общество, культуры, смыслы. 2020. Т. 11. № 2

\section{Базовые постулаты исламского фундаментализма}

Исламский радикализм как политическое явление в своем практическом воплощении привязан к конкретным социально-экономическим, культурным и иным реалиям мусульманского социума, в котором он возникает. Вместе с тем, исходя из ретроспективного анализа фунадменталистских движений в исламских государствах и обществах, можно сделать вывод, что все они в значительно степени опираются на общий идейно-смысловой фундамент, основа которого была заложена еще в Средние века.

В настоящее время большинство исследователей сходятся во мнении, что истоки радикального ислама (ваххабизма, салафизма) следует искать в одной из мусульманских богословско-правовых школ (мазхабов), а именно в Ханбалитском мазхабе. Данная школа является одним из четырех официально признаваемых в суннитском мире мазхабов (наряду с маликитским, шифиитским и ханафитским). Основателем данного течения является исламский юрист и богослов Ахмад ибн Ханбаль (780-855). В его эпоху в Аббасидском халифате набирало силу течение мутазилитов («обособившихся»), адепты которого исходили из религиозной рациональности, в том числе рукотворности Корана. Насаждение халифом аль-Мамуном (786-833) мутазилитских постулатов, безусловно, сказалась на мировоззрении ибн Ханбаля, который за свои традиционалистские убеждения и отказ признавать новые догматы даже получил два года тюремного заключения [2, с. 222]. Он учился у Мухаммада аш-Шафии (767-820), основоположника шафиитской правовой школы, однако взгляды Ахмада ибн Ханбаля были гораздо более консервативны. Это, вероятно, связано с тем, что во времена аш-Шафии, который к тому же в последние годы своей жизни вообще абстрагировался от политических вопросов, позиции мутазилитов в халифате не были столь сильны, как в эпоху ибн Ханбаля (начиная с 813 г.).

Главным трудом имама Ахмада стал сборник «Муснад», содержащий более 30 тыс. хадисов [26]. При этом большинство исламоведов утверждают, что сам ибн Ханбаль, хоть и считается уважаемым факихом («знающим»), никогда не писал книг по фикху (исламскому праву) [25, p. 76]. То есть де-факто, как утверждает доктор наук в сфере мусульманского права Мединского Исламского Университета Шейх Амир Бахджат, он не составлял свой мазхаб [4]. И его фетвы (решения), на основе которых фактически и был сформирован ханбалитский мазхаб, были записаны его учениками, среди которых особое место занимает Абу Дауд (автор сборника хадисов («Сунан Абу Дауда») и сыновья Ахмада ибн Ханбаля (Абдуллах и Салих). Это крайне важно, 
т.к. позиция ибн Ханбаля по многим вопросам, где мнения сторонников различных мазхабов принципиально различаются, достоверно неизвестна [25, р. 75]. Например, это касается вопроса поклонения могилам и чтения Корана над ними, что современными салафитами (по большей части сторонниками ханбалитского масхаба, хотя существуют и исключения) однозначно считается ширком (многобожием) [15, с. 110]. В этом они регулярно обвиняют своих идеологических противников - суфиев, считая их фактически еретиками, ссылаясь в т.ч. и на самого ибн Ханбаля. Однако в одном из хадисов «Муснада» имам Ахмад говорит о халифе Марване I (623 685), который увидел сподвижника пророка Мухаммеда Абу Айюбе (576-674), приложившего голову к могиле посланника Бога [26].

В целом, основные положения, которым должна следовать мусульманская община по ханбалитскому мазхабу, выглядят следующим образом. Прежде всего за базовую модель не только поведения мусульманина, но и подхода к толкованию Корана и Сунны, а также выведению из них иных религиозно-правовых положений и норм, должен быть взят пример самого пророка Мухаммада и его сподвижников. Необходимо стараться наиболее точно придерживаться их образа жизни. Толкование Корана и Сунны не должно производится путем рационализма и логики. Это их кардинально отличает от более либеральных ханафитов, которые считают нормальным использование кыяса, т.е. исламского аналога прецедента - суждения по аналогии с ситуациями из Корана и Сунны, в вопросах, по которым в Священном писании не дается четкого ответа. Между течениями по этому вопросу существует спор. В частности, ханафиты аргументируют возможность использования кыяса 59 аятом, 4 суры Корана, в котором говорится «если же вы станете препираться о чем-нибудь, то обратитесь с этим к Аллаху и Посланнику, если вы веруете в Аллаха и Последний день» [17]. Ханбалиты же приводят слова сына имама Ахмада, Абдуллаха, который донес до мусульман позицию отца по данному вопросу. Он пишет о том, что даже «слабый хадис сильнее суждения» [1]. Различное отношение существует также и к иджме (согласованное мнение исламских правоведов по какому-либо вопросу), к которой ханбалиты фактически не прибегают вообще. Все последующие нововведения (бида), как в вопросах права и богословия, так и в бытовых аспектах, которые не находят прямого подтверждения в Коране, хадисах, а также среди согласного мнения первых трех поколений исламских авторитетов («праведных предков»), должны быть отвергнуты как ложные и искажающие религию. По их мнению, законно только то, что предписано Кораном и Сунной, и в первоначальном виде [15, с. 110]. 
Впоследствии идеи ибн Ханбаля развил богослов Ибн Таймия (1263-1328). Он жил в достаточно тяжелый период для мусульманской общины Ближнего Востока, связанный с монгольскими завоеваниями. В 1268 г. его семья была вынуждена покинуть родной г. Харран и переселилась в Дамаск. Кроме того, в эту эпоху, как отмечал башкирский исламовед конца XIX - начала XX вв. Ризаитдин Фахретдинов, все чаще в Мамлюкском султанате ислам становился методом для спекуляций так называемыми «торговцами религией» [19, с. 24]. Эти факты безусловно повлияли на взгляды Ибн Таймии.

Его работы, в основном, были сфокусированы на трех базовых, по его мнению, положениях ислама. Во-первых, это принцип единобожия (таухид) в его наиболее радикальном проявлении: провозглашается не только, что Аллах единое и единственное божество, достойное поклонения (что в принципе разделяется всеми мусульманами), но и отвергается принципиальная возможность наличия каких-либо «звеньев» посредников между Богом и людьми, а любые проявления поклонения или почитания кого-либо в религиозном плане рассматриваются как проявление многобожия и отпадение от ислама. В отличие от имама Ахмада, он достаточно недвусмысленно обозначил позицию на этот счет. В книге «Маджму Аль-Фатава» он писал, что «признание единства Божества выражается в совершении поклонений исключительно Ему, без придания Ему сотоварищей в чем-либо, что касается божественности» [27]. Кроме того, в работе «Аль-Икна» он указал на то, что «кто вознесет молитву к мертвому, станет кафиром (“неверным”), даже если тот, кому направлена мольба, является праведным халифом. Кто сомневается в неверии такого человека, тоже неверный» [10, с. 240]. Ибн Таймия был убежден в том, что «целовать могилы, совершать обход вокруг них с целью поклонения и их возвеличивания и пытаться приблизиться к Аллаху посредством обетов и жертвоприношений запрещено» [19, с. 69].

Таким образом, указанная доктрина изначально вступает в жесткое противоречие, в частности, с практиками суфиев, среди которых был распространен культ святых, молитвы на могилах праведников и т.д. Большинство как отечественных, так и зарубежных ученых сходятся во мнении, что Ибн Таймия исключительно отрицательно относился к тарикатистам (ровно как и к друзам и алавитам), обвиняя их в ширке. И это в целом находит подтверждение в его трудах, в частности, он отрицает возможность мюридско-муршидских отношений (взаимосвязь ученика и его духовного наставника у суфиев), дервишество и т.п. [Там же, с. 81]. Хотя отдельные ученые, например, Яхья Мишот (Yahya Michot) указывают на то, что ибн Таймия порицал лишь 
отдельные суфийские практики, но при этом с большим уважением относился ко многим духовным деятелям, стоявшим у истоков тарикатизма [24, р. 123].

Во-вторых, как уже отмечалось выше, ибн Таймия исключает возможность при толковании Корана и Сунны обращения к «философским методам» (калам), рационалистическому выведению новых правовых норм из положений связанных текстов, а также безоговорочному следованию мнению авторитетов существующих мазхабов. Ибн Таймия называет калам вариантом еретичества, из-за которого его адепты в конце жизни не могут найти себя и «оказываются в смятении». Он писал о том, что они либо встанут на «путь большинства», либо так и не смогут «познать истину» [27].

В-третьих, отрицаются как ложные любые нововведения в религиозной (к ним он относил и калам) и бытовой практике, которые не восходят ко временам основателя ислама и праведных предков. По мысли ибн Таймии, основная угроза «чистому исламу» состоит в допущении аллегорического или же, напротив, чрезмерно рационального понимания и истолкования священных текстов. Человеческий разум не способен во всем объеме постичь божественный замысел, значит, попытка рационалистического толкования и объяснения норм ислама, а тем более применение основанных на человеческом разуме методов по выведению новых правовых норм, неизбежно приводит к появлению искажающих религию нововведений и отдаляет мусульманскую общину от первоначального (истинного понимания) смысла указанных норм и текстов.

Ибн Таймия порицал мусульманских богословов и политических лидеров, которые, на его взгляд, отступили от истинного ислама. В целом, богослов с уважением относился к власти (как религиозной, так и политической), считая ее необходимой составляющей для стабильности общества, подкрепляя свои доводы строками из 62 аята 4 суры Корана [17]. Он говорил, что «носители власти бывают двух видов: эмиры и улемы; если они поступают правильно, то и люди поступают правильно. Правители могут не являться знатоками шариата, но тогда они прибегают к советам улемов. Именно надлежащее взаимодействие правителей и улемов позволяет осуществлять следование шариату» $[11$, с. 138]. При этом в «Маджму Аль-Фатава» он указывает на то, что люди имеют право свергнуть правителя, если тот является «неверным» [26]. Как отмечает Л.Б. Маевская, относительно того, можно ли обвинить в такфире конкретного человека, в трудах факиха наблюдается некая двусмысленность [10, с. 241], порождающая споры среди мусульманских правоведов. 
Большое значение в своих работах Ибн Таймийя уделял также и понятию джихада (священной войны с неверными), которое, исходя из принципов и подходов, описанных выше, также во многом толковался им прежде всего в буквальном значении необходимости вооруженной борьбы с противниками ислама. В частности, в работе «Гурбату аль-Ислам» он пишет, что «ученые мусульман единогласно сошлись на том, что если группа отказывается выполнять некоторые обязательные, общеизвестные, явные положения ислама, то поистине, является обязательным сражаться с ними» [10, с. 241]. Ибн Таймия принимал непосредственное участие в сражении у Шахаба против монголо-татар, которых он считал «неверными» (даже тех, кто исповедовал ислам). Кроме того, он выносил такфир всем, кто причислял себя к мусульманам, но не соблюдал пять столпов ислама и иные общеизвестные правила поведения адептов этой религии. Джихад в отношение них он считал богоугодным делом. В то же время он утверждал, что совершившие ширка или куфра по незнанию могут быть оправданы Аллахом.

Стоит отметить, что подобный радикальный подход указанного автора, как впрочем, и ряда более поздних (включая современных идеологов исламского радикализма), совпал и во многом являлся реакцией мусульманского социума на внешнюю агрессию и переживаемый кризис. С учетом того, что ислам сам по себе тесно связан и практически неотделим от политики, рост «политических рисков» мусульманским государствам и обществам практически всегда являлся импульсом к развитию в них радикальных идей, призывающих «вернуть» ислам к его первоначальному виду и на этой основе вести вполне конкретную политическую и военную борьбу с враждебными как внешними, так и внутренними силами.

\section{Некоторые аспекты практического воплощение исламских фундаменталистских идей в политической практике мусульманских государств}

Кратко рассмотрев истоки и основные положения исламского фундаментализма, перейдем к историческому анализу конкретных примеров практического воплощения указанных идеологических построений в политической жизни мусульманских государств и обществ. Одним из первых и наиболее ярких деятелей, воплотивших идеи исламского фундаментализма, в частности, ибн Ханбаля и ибн Таймии, стал Мухаммад ибн Абд аль-Ваххаб (1703-1792) - основоположник ваххабизма и один из создателей саудовского государства во второй половине XVIII в. В своем основном труде «Китабат-Таухид» [27] (Книге 
единобожия) аль-Ваххаб развивал идеи, в принципе, схожие с основными положениями ибн Таймийи: отказ от всех нововведений, возврат к «истинному» единобожию, искоренение неисламских племенных традиций и обычаев тогдашней Аравии. В частности, в подразделе 4 «О необходимости боязни ширка» он называет ширк самым страшным из грехов, который не может быть прощен Аллахом и совершивший его (мушрик) «проведет вечность в огне» [28]. Для доказательства своей позиции о недопустимости многобожия и идолопоклонства он приводит 13 аят 35 суры Корана, в которой сказано, что у них «нет власти над небесами и землей даже в размере с плеву финиковой кости» [17]. Его позиция выглядит более радикальной, чем у Ибн Таймии, который допускал возможность прощения этого греха в случае его совершения «в неведении».

В своих трудах он также порицает различные суеверия, ношения амулетов, поклонения святым и умершим, а не Аллаху и иные практики, присущие суфийским орденам.

Важным залогом успеха ваххабизма стала способность его основателя преподнести основные положения фундаментализма (в рамках ханбалитского мазхаба) в качестве политического инструмента. Аль-Ваххаб, в частности, призывал к искоренению социального неравенства, взяточничества, межплеменной вражды и других социальных пороков и установление «истинного» мусульманского правления на основе шариата, при котором всем членам исламского социума будут гарантированы равные права и достойные социально-экономические условия жизни, как во времена «золотого века» ислама. Проповедь ибн Абдаль-Ваххаба совпала также с постепенным началом упадка Османской империи - ключевого мусульманского государства того времени (османский султан носил титул халифа), которое постепенно начало превращаться в «больного человека Европы» и теряло контроль над своими владениями, в том числе в Северной Африке и на Аравийском полуострове. Аль-Ваххаб активно выступал против османского господства, используя религиозный фактор - с точки зрения ваххабизма религия турецких властей не является «чистым» исламом, т.к. слишком «засорена» нововведениями. Таким образом, в действительности османский султан не может носить титул халифа и не является законным лидером правоверных [11, с. 112]. Подобная радикальная и антитурецкая направленность проповеди аль-Ваххаба была поддержана рядом представителей арабской знати, в частности, рода альСайд (Дирийский эмират), которые, взяв на вооружение ваххабитскую идеологию, смогли объединить под своей властью значительную часть центральной Аравии к концу XVIII в. 
Впоследствии радикальные исламские идеи стали находить все больше поддержки и в других частях мусульманского и арабского (как составной его части) мира. Во второй половине XIX в. он стал объектом колониальных устремлений ведущих государств Запада. Окончательное политико-экономическое разложение Османской империи и общий социально-культурный упадок на Ближнем Востоке и в Северной Африке поставил перед ведущими исламскими мыслителями вопрос о поиске причин такого бедственного положения и выработке адекватного ответа на имеющиеся угрозы и вызовы, причем как в религиозной, так и в политической плоскостях. Одним из первых ответов мусульманского мира стало сформированное под влиянием исламского деятеля второй половины XIX в. Джамаля ад-Дина Афгани (1838-1897) движение т.н. панисламизма, основой которого должно было стать создание своеобразного религиозно-политического союза мусульманских народов. Афгани видел в исламе единственное объединяющие начало для народов Востока. Только на основе ислама восточные общества могут гарантировать себе успешное социально-политическое и экономическое развитие, а также обеспечить себе освобождение (или защиту) от колониального гнета европейских держав.

По мнению Афгани, все мусульманские народы должны были приложить усилия для спасения «терпящего бедствия корабля ислама» [14, с. 112] на базе его панисламистской концепции. Самым главным в ней был отказ от идеологических парадигм, непригодных для развития мусульманского социума. Ислам, по мысли Афгани, сам является полностью самодостаточной не только религией, но и основой государственного строя и цивилизацией - универсальным решением для общества любой эпохи и стадии развития [6, с. 12].

Панисламизм Афгани был направлен, в первую очередь, на объединение усилий всей мусульманской уммы в борьбе с колониальной экспансией Запада; он являлся исламским ответом на культурно-идеологический вызов европейской цивилизации, стремящейся навязать обществам востока чуждые для них ценности, а также на определенную унификацию самой исламской религии, преодоление разногласий между множеством различных течений и сект. Указанные цели в практической плоскости предполагали создание единой исламистской политической идеологии, которая впоследствии должна была найти свое воплощение в едином государстве, объединяющим всех мусульман $[14$, с. 113].

Однако в действительности надежды Афгани на объединение мусульманских обществ под знаменами ислама в борьбе против колонизаторов не оправдали себя. После крушения Османской империи Ближний 
Восток был поделен на подмандатные территории - единого мусульманского (арабского) государства создать не удалось, продолжилась экспансия в регион западной, секулярной культуры. На этом фоне в мусульманской среде вновь стали активно развиваться радикальные политические идеологии на религиозной основе.

К относительно умеренному крылу исламистских идеологов относится основатель партии «Джамаат-и-Ислами» индийский религиозный деятель середины ХХ в. Абу-ль-Аля Маудуди (1903-1978), выдвинувший концепцию «исламского государства» на основе четырех основных принципов: власть в таком государстве принадлежит исключительно Аллаху (правительство выполняет функцию представителя/заместителя Бога на земле); основу законодательства составляют нормы шариата; любые вновь принимающие законы не должны противоречить шариату; государственные деятели не должны преступать границ, установленных религией [5, с. 113]. Оптимальной формой государственного устройства, по мнению Маудуди, является синтез теократии и демократии - во главе страны должны стоять «улемы нового типа». Он считал, что исламское сообщество должно быть выше этнических, племенных, региональных, расовых различий, а тем более хозяйственных факторов [16, с. 121]. Установление подобного государства мыслилось им как результат революции, т.е. вооруженной борьбы. В данном контексте Маудуди поддерживал расширительную трактовку джихада и допускал его ведение не только в оборонительных, но и в наступательных целях для превентивного удара по «врагам ислама» [18, с. 118]. «Джихад, как писал Муадуди, - представляет собой часть всеобщей защиты ислама и обозначает борьбу до последней капли крови... Джихад является такой же обязанностью мусульман, как ежедневная молитва и пост. Тот, кто уклоняется от этого, является грешником» [23, р. 48]. Несмотря на большое значение, придаваемое Маудуди разработке идеи джихада как вооруженной борьбы, в целом его практическая деятельность была больше сосредоточена на ненасильственных политических методах, таких как организация пропагандистской работы, участие в выборах, развитие исламского образования.

Гораздо с более радикальных позиций выступал основатель египетской организации «Братья-мусульмане» Хасан аль-Банна (1906-1949). Он жил в эпоху становления независимости египетского государства и его борьбы за полный суверенитет от британской короны. Позиция аль-Банны во много продиктована обстановкой, сложившейся в мире в общем, и в Египте - в частности. Это видно уже по предисловию к его работе «Путь джихада», написанному исламоведом и богословом Ама Фахми, где говорится о том, что «мусульманский мир сталкивается 
с тиранией и несправедливостью и подвергается притеснениям со стороны ведущих военных и экономических держав» [20].

В отличие от концепций панисламизма Афгани и «исламского государства» Маудуди, которые являлись больше политическими идеологиями, делавшими упор на ненасильственные, пропагандистские методы, парадигма «Братьев-мусульман» отличалась направленностью на конкретные действия по борьбе с их идеологическими противниками, в том числе с активным применением насилия («Метод наш - убеждение и совет, а если это не помогает - то искоренение силой и устранение») [8, с. 193]. Таким образом, у аль-Банны на первый план выходит понятие джихада [3, с. 29]. В труде «Путь джихада» он писал, что священная война является обязанностью для мусульманина и от нее ни в коем случае нельзя уклоняться. По его словам, Аллах наделил моджахедов («воинов джихада») исключительными духовными и иными качествами, которые помогут им победить. В труде аль-Банны говорится, что Господь щедро наградит мучеников и борцов за веру [20]. Важность борьбы с неверными он подтверждает строками из Корана и словами уважаемых исламских религиозных деятелей. В частности, сура 9 аят 29 Корана: «Сражайтесь с теми из людей Писания, которые не веруют ни в Аллаха, ни в Последний день, которые не считают запретным то, что запретили Аллах и Его Посланник, которые не исповедуют истинную религию, пока они не станут собственноручно платить дань, оставаясь униженными» [17] (существуют и иные трактовки данного аята). Или же 60 аят 8 суры: «Приготовьте против них сколько можете силы и боевых коней, чтобы устрашить врага Аллаха и вашего врага, а также тех, которых вы не знаете, но которых знает Аллах. Что бы вы ни израсходовали на пути Аллаха, вам будет возвращено сполна, и с вами не поступят несправедливо» [Там же].

Разделяя взгляды Афгани на универсальность ислама (ислам - это «вера и общество, мечеть и государство»), аль-Банна призывал к установлению «исламского порядка» в государстве. Ислам должен стать не просто религиозным мировоззрением, но идеологией активного политического действия, направленным на борьбу с политическими оппонентами. Как говорил аль-Банна, «Мы призываем вас к исламу $<\ldots>$ правительство - часть его, а свобода - одна из религиозных обязанностей. Если кто-либо скажет вам: “Это политика”, скажите: “Это ислам, и мы не признаем никакого разделения"» [3, с. 30].

Еще одной значимой фигурой, оказавшей существенной влияние на развитие исламского радикализма, является главный идеолог «Братьев-мусульман» египтянин Сейид Кутб (1906-1966). По мысли Кутба, весь мир разделен на два типа обществ: исламские, где социум живет по законам Шариата, и языческие, т.е. те, где люди сами 
создают и устанавливают для себя законы и нормы поведения. Большинство современных государств являются языческими, причем в это число входят и те страны, которые формально причислят себя к исламским и где ислам установлен в качестве государственной религии, но в реальности не живут по законам Аллаха. Восстановить подлинную власть исламского закона в указанных обществах можно путем активной борьбы с невежеством (джахилией), которая распространяется через культуру, искусство, литературу, различные псевдорелигиозные культы, активно продвигаемые западным миром. Участие в борьбе с джахилией и теми людьми, кто способствует ее распространению, обязанность каждого правоверного мусульманина.

Основой такой борьбы должен стать вооруженный джихад против неверных. Кутб на основе Корана выделяет несколько степеней джихада, при этом признавая наиболее совершенным и основным универсальный джихад против всех неверных, независимо от их отношения к исламу [14, с. 116]. Джихад носит вневременной и наднациональный характер и не может быть ограничен каким-либо конкретным историческим периодом, политической конъюнктурой или иными обстоятельствами. Универсальность и всеохватность ислама как религии, о чем уже упоминалось выше, объективно диктует также такие черты джихада, как активный и наступательный, а не сугубо оборонительный характер. Как писал Кутб в своей книге «Война, мир и исламский джихад», «Мусульманин должен жертвовать на пути Аллаха всей своей жизнью и достоянием ради утверждения идеалов, в которых для него не заключено никакой личной выгоды или корысти. Выбрав джихад и выйдя на поле брани, мусульманин уже оказывается победителем в великой схватке, составляющей суть джихада» [9] .

Кутб считает необходимым также мирную проповедь и призыв к исламу, однако если это не помогает, необходим переход к вооруженной борьбе для установления подлинного «исламского порядка». Он, в частности, отмечал следующее: «Наша религия (ислам. - Б.М.) тождественная полной и всеобъемлющей революции против людской власти во всех ее проявлениях и разновидностях, включая все виды и типы государственного устройства. Она неуклонно восстает против любой системы, так или иначе основанной на человеческом авторитете, т.е. против любой формы узурпации власти человеком» [Там же].

Конечной целью данной борьбы должно стать уничтожение джахилии, установление новой социально-экономической и политической системы, в которой человек, полностью освобожденный от влияния языческих представлений и культурных наслоений, сможет в добровольном порядке выбрать ислам как единственную истинную религию. 
Кроме того, возможность сочетания ислама с социализмом или демократией, что было актуально для Египта 1950-1960-х гг., он категорически отвергал: «Я не перевариваю речей тех, кто рассуждает о “социализме ислама”, “демократии ислама” и т.п., смешивая порядок, сотворенный богом, и порядки, созданные людьми. Ислам дает самостоятельные, независимые решения проблем человечества. Он - интегральный метод и гармоническое единство, и введение в него любого постороннего элемента способно испортить его так, как включение ненужной детали в сложный механизм может привести весь механизм в негодность» [7, с. 191].

Труды Хасана аль-Банны и Сейида Кутба имеют неоднозначную репутацию в мусульманском мире. С одной стороны, большинством современных мусульман, особенно не разделяющих радикальные идеи, они воспринимаются скорее отрицательно и ассоциируются с религиозным экстремизмом. С другой стороны, ряд уважаемых исламских деятелей, являющихся адептами ханбалитского мазхаба и придерживающихся салафитских взглядов, которых вряд ли можно причислить к экстремистам, такие как саудовский религиозный деятель Абд аль-Азиз ибн Баз, албанский богослов Насируддин аль-Албани и хадисовет Хамуд ибн Укаля, указывают на полезность их трудов. Ибн Альбани даже говорил про Сейида Кутба: «мы чтим его за его джихад» [13].

В дальнейшем идеи исламского радикализма, признающего основным методом достижения своих политических целей вооруженную борьбы (джихад), нашли свое отражение в деятельности исламистских террористических группировок конца XX - начала XXI вв., наиболее значимой из который стала «Аль-Каида». Лидер данной организации Усама бен Ладен вслед за Кутбом придерживался точки зрения о необходимости ведения «тотального джихада» против как западных государств, распространяющих в исламском мире секулярную идеологию и враждебную исламу культуру, так и против коррумпированных авторитарных режимов мусульманских государств, правители которых отступили от чистого ислама. Провозглашение вооруженной борьбы против «сионистов и крестоносцев» и их приспешников в мусульманских странах виделось основателям «Аль-Каиды» как первый шаг на пути к «очищению ислама» и началу построения нового справедливого общества, идеалом которого является первая мусульманская община времен «праведных предков». В 1998 г. он призвал к вооруженному джихаду против американцев: «Решение убить американцев и их союзников - гражданских и военных - является индивидуальной обязанностью каждого мусульманина, который может сделать это в любой стране» [21]. 
Кроме того, в идеологии бен Ладена важнейшее место занимает концепция мученичества и божественной награды участникам вооруженного джихада против неверных: «В загробном мире всем, посвятившим себя джихаду, уготовано особое место... Погибнуть по имя дела Аллаха - величайшая честь, которой удостоятся только те, кто составляет цвет нации» [10, p. 192].

Глобальность понятия джихада более полно раскрывает в трудах другого идеолога «Аль-Каиды» Аймана аз-Завахири. В частности, в своей книге «Рыцари под знаменем Пророка» он указывает, что джихад является вооруженной борьбой против неверных в широком смысле, т.е. против всех сил, препятствующих распространению ислама и искажающим его. В список врагов «истинной веры» таким образом попали, помимо западных стран и России, также и ООН, дружественные неверным мусульманские режимы, транснациональные корпорации, международные информационные агентства, международные (гуманитарные) организации и т.д.

Подводя итог, можно констатировать, что на протяжении истории исламский радикализм периодически получал существенное распространение как один из ответов мусульманского мира, с одной стороны, на внешнее давление, а с другой - на процессы, происходящие внутри него самого, которые определенная группа «ревнителей» трактовала как отступление от истинного смысла данной религии. В своих теоретико-идеологических построениях исламские радикалы традиционно опираются на инструментарий, выработанный еще основателями ханбалитского мазхаба и рядом других авторитетных религиозных деятелей прошлого. Основными постулатами исламизма является призыв к «очищению» ислама и построения на его основе нового государства, идеалом которого является община верующих времен пророка Мухаммада и его сподвижников. При этом одним из основных способов достижения указанной цели является ведение вооруженной борьбы с неверными, которая трактуется в самом широком смысле, в т.ч. и в наступательном ключе (не только крайними радикалами, но и идеологами умеренного исламизма).

\section{Библиографический список / References}

1. Аввама М. Роль хадиса в расхождениях между имамами фикха. 6 урок. Можно ли практиковать слабые хадисы? 2015. URL: https://azan.ru/durus/ read/6-urok-mozhno-li-praktikovat-slabyie-hadisyi-nachalo-1656 (дата обращения: 28.03.2020) [Avvama M. Rol hadisa v raskhozhdeniyah mezhdu imamami fikkha. Mozhnolipraktikovat' slabyehadisy? [The role of hadith in the differences between the imams of fiqh. Sixth lesson. Is it possible 
to practice weak hadiths?]. 2015. URL: https://azan.ru/durus/read/6-urokmozhno-li-praktikovat-slabyie-hadisyi-nachalo-1656. (In Russ.)]

2. Алонцев М.А. “Ты не назвал Коран сотворенным": Ахмад ибн Ханбал // Шаги. 2016. № 2 (2-3). С. 221-228. [Aloncev M.A. "You did not call the Qur'an created": Ahmad Ibn Hanbal. Steps. 2016. No. 2 (2-3). Pp. 221-228. (In Russ.)]

3. Багдади А. Идейные истоки и идеология исламского фундаментализма. M., 1998. [Bagdadi A. Idejnye istoki i ideologiya islamskogo fundamentalizma [The ideological origins and ideology of Islamic fundamentalism]. Moscow, 1998.]

4. Бахждат А. Имам Ахмад. Ханбалитский мазхаб // Научно-познавательный канал «Минхаджас-Сунна». URL: https://www.youtube.com/ watch?v=o4fMxTeYVlY\&feature=emb_title (дата обращения: 28.03.2020) [Bahzhdat A. Imam Ahmad. Hanbalitskij mazkhab [Imam Ahmad. Hanbalith madhhab]. Minhaj Sunna. URL: https://www.youtube.com/

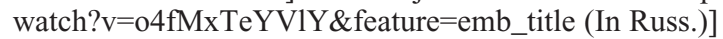

5. Гареева Г. Исламский фундаментализм и опыт государственного строительства в Пакистане // Россия и мусульманский мир. 2001. № 12. С. 112 116. [Gareeva G. Islamic fundamentalism and the experience of state building in Pakistan. Russia and the Muslim World. 2001. No. 2. Pp. 112-116. (In Russ.)]

6. Жданов Н.В. Исламская концепция миропорядка. М., 2003. [Zhdanov N.V. Islamskaya koncepciya miroporyadka [The Islamic concept of world order]. Moscow, 2003.]

7. Игнатенко А.А. Халифы без халифата. Исламские неправительственные религиозно-политические организации на Ближнем Востоке: история, идеология, деятельность. М., 1988. [Ignatenko A.A. Halify bez halifata. Islamskie nepravitelstvennye religiozno-politicheskie organizacii na Blizhnem Vostoke: istoriya, ideologiya, deyatelnost [Caliphs without a Caliphate. Islamic nongovernmental religious and political organizations in the Middle East: History, ideology, and activities]. Moscow. 1988.]

8. Ислам в современной политике стран Востока (конец 70-х - начало 80-х годов XX в.) / Отв. ред. Л.Р. Полонская. М., 1986. [Islam v sovremennoj politike stran Vostoka (konec 70-h - nachalo 80-h godov XX v.) [Islam in the modern politics of the East (late 70's - early 80's of the XX century)]. L.R. Polonskaya (ed.). Moscow, 1986.]

9. Кутб С. Война, мир и исламский джихад // Отечественные записки. 2003. № 5 (14). URL: http://www.strana-oz.ru/2003/5/voyna-mir-i-islamskiydzhihad (дата обращения: 05.11.2019) [Qutb S. War, peace and Islamic Jihad. Otechestvennye zapiski. 2003. No. 5 (14). URL: http://www.strana-oz. ru/2003/5/voyna-mir-i-islamskiy-dzhihad (In Russ.)]

10. Маевская Л.Б. Роль такфира (обвинения в неверии) в учении Ибн Таймии // Modern Science. 2019. Vol. II. № 7. C. 236-245. [Mayevskaya L.B. The Role of Takfir (accusations of disbelief) in the teachings of Ibn Taymiyyah. Modern Science. 2019. No. 7. Pp. 236-245. (In Russ.)]

11. Маточкина А.И. Обращение к идеям Ибн Таймийи в новое и новейшее время // Ученые записки Казанского университета. Сер. Гуманитарные науки. 2013. C. 111-119. [Matochkina A.I. Appeal to the ideas of Ibn Taymiyyah in the new and modern times. Uchenye Zapiski Kazanskogo Universiteta. Seriya Gumanitarnye Nauki. 2013. Pp. 111-119. (In Russ.)] 
12. Маточкина А.И. Идеи социальной справедливости и равенства во взглядах Ибн Таймийи // Asiatica: Труды по философии и культурам Bocтока. 2019. № 1. C. 132-143. [Matochkina A.I. Ideas of social justice and equality in the views of Ibn Taymiyyah. Asiatica. 2019. No. 1. Pp. 132-143. (In Russ.)]

13. Отведение великого обмана от Сейид Кутба и Хасана аль-Банна. Ar-Rad.ru. URL: https://www.youtube.com/watch?v=O7-wuKf5JUs (дата обращения: 01.04.2020). [Otvedenie velikogo obmana ot Sejid Kutba I Hasana al'-Banna [Diverting the great deception from Sayyid Qutb and Hasan al-Banna]. URL: https:/www.youtube.com/watch?v=O7-wuKf5JUs (In Russ.)]

14. Петрухина А.А. Влияние взглядов Дж. Афгани, Х. Аль-Банны, А. Маудуди, С. Кутба на становление и распространение исламистской идеологии // Контуры глобальных трансформаций: политика, экономика, право. 2012. № 3 (23). C. 112-118. [Petrukhina A.A. Influence of views of J. al-Afgani, H. al-Banna, A. Maududi, S. Qutb on the formation and spread of Islamist ideology. Kontury global'nykh transformatsii: politika, ekonomika, pravo. 2012. No. 3 (23). Pp. 112-118. (In Russ.)]

15. Раджабов Р.А. Основные конфессиональные противоречия между суфизмом и ваххабизмом // Исламоведение. 2009. № 2. С. 107-115. [Radzhabov R.A. The main confessional contradictions between Sufism and Wahhabism. Islamic Studies. 2009. No. 2. Pp. 107-115. (In Russ.)]

16. Родригес-Фернандес А.М. Исламская традиция и стратегии национального развития арабских государств // Локус: люди, общество, культуры, смыслы. 2020. № 1. С. 117-128. DOI: 10.31862/2500-2988-2020-1-117-128 [Rodriges-Fernandes A.M. Muslim tradition and conceptions of national development of Arab states. Locus: People, Society, Culture, Meanings. 2020. No. 1. Pp. 117-128. DOI: 10.31862/2500-2988-2020-1-117-128 (In Russ.)]

17. Священный Коран / Пер. на рус. яз. подгот. Э. Кулиев. М., 2002. [Svyashchennyj Koran [The Holy Quran]. E. Kuliev (translation into Russian). Moscow, 2002.]

18. Семедов С.А. Ислам в политике: идеология и практика. М., 2009. [Semedov S.A. Islam v politike: ideologiya i praktika [Islam in politics: Ideology and practice]. Moscow, 2009.]

19. Фахретдин Р. Ибн Таймийа / Пер. со старотатарского. М., 2018. [Fakhretdin R. Ibn Tajmija [Ibn Taymiyyah]. Moscow, 2018.]

20. Al Banna H. The Way of Jihad: Complete Text. Militant Islam Monitor. URL: http://www.militantislammonitor.org/article/id/379 (accessed: 01.04.2020).

21. Bin Laden U.S., al-Zawahiri A., Taha Y.R. et al. World Islamic Front Statement: Jihad against Jews and Crusaders. Federation of American Scientists. URL: https://fas.org/irp/world/para/docs/980223-fatwa.htm (accessed: 01.04.2020).

22. Fandy M. Saudi Arabia and the politics of dissent. NY., 1999.

23. Maududi A.A. Islamic law and constitution. Lahore, 1960.

24. Michot Y. Ibn Taymiyya's commentary on the creed of al-Hallaj. Sufism and Theology. Ayman Shihadeh (ed.). Edinburgh University Press, 2007. Pp. 123-135.

25. Zargar C. Origins of Wahhabism from Hanbali Fiqh. Journal of Islamic and Near Eastern Law. 2017. № 16 (1). Pp. 65-114. 
26. أحمدبنحنبلمسندالإمامأحمد

Musnad of Ahmad Ibn Hanbal. Cairo, 1995. Vol. 1. URL: https://ia800302. us.archive.org/10/items/waqmusnda/musnda01.pdf (accessed: 01.04.2020). (In Arabic)

27. مجمو عةالفتاو بابنتيمية

Ibn Taymiyyah. Majmu' al-Fatawa. Cairo, 2017. URL: https://archive.org/ details/mfsiaitmmfsiaitm/mode/1up (accessed: 01.04.2020). (In Arabic)

28. محمّدبنعبدالو هِابالمشرّفيالتميميكتابالتو حيد

Muhammad bin Abdul Wahhab. The Book of Monotheism. Dar-usSalam Publications, 1996. URL: https://ia800303.us.archive.org/30/items/ WAQ97861_154/97861.pdf (accessed: 01.04.2020). (In Arabic)

Статья поступила в редакцию 05.11.2019, принята к публикации 30.04.2020

The article was received on 05.11.2019, accepted for publication 30.04.2020

\section{Сведения об авторе / About the author}

Маргулис Сергей Борисович - преподаватель кафедры международной политики и зарубежного регионоведения Института общественных наук, Российская академия народного хозяйства и государственной службы при Президенте Российской Федерации, г. Москва

Sergey B. Margulis - lecturer at the Department of International Policy and Regional Studies of the Institute of Social Sciences, Russian Presidential Academy of National Economy and Public Administration, Moscow

E-mail: sergeimargulis@mail.ru 